\title{
Properties of Some Selected Soil under Mymensingh District in Bangladesh
}

\author{
MD. Tohidul ISLAM ${ }^{1}$, MD. SERAZUl ISLAM ${ }^{2 *}$ AND Md. NurUl HoQUE ${ }^{3}$ \\ ${ }^{1}$ Engineering Section, Bangladesh Agricultural University, Mymensingh, Bangladesh \\ ${ }^{2}$ School of Agriculture and Rural Development, Bangladesh Open University, Gazipur, Bangladesh \\ ${ }^{3}$ Department of Farm Structure, Bangladesh Agricultural University, Mymensingh, Bangladesh
}

Received 30 May 2006; received in revised form 20 June 2006; accepted 22 June 2006

\begin{abstract}
This paper elucidated an attempt to determine the physical properties of some selected soils at different location under Mymensingh districts. The properties of soils were determined using standard methods. Field moisture content was more or less similar for all the locations. The dry unit weights of selected seven soils for Bangladesh Institute of Nuclear Agriculture (BINA), Valuka, Muktagacha, Trisal, Madhupur, Chorkhai and Shomvoganj sites were found to be 17.61, 16.50, 17.00, 17.50, $15.50,16.40$ and $16.20 \mathrm{kN} / \mathrm{m}^{3}$, respectively while the specific gravities were found as $2.67,2.66$, $2.68,2.70,2.69,2.72$ and 2.65, respectively also the values of plastic limits of soils were found to be $16.00,17.00,15.50,18.50,16.00,17.20$ and 14.00 percent, respectively whereas the plasticity index values were 16.25, 14.50, 15.00, 17.00, 18.00, 13.60 and 15.50 percent, respectively for the above locations. The liquid and plastic limits varied for all the locations but the plasticity index values were found more or less similar for all the soil samples. The friction angles were found more or less similar while cohesion varied for different locations. The properties of soils thus obtained can be used for soils of these areas of Bangladesh. A relation between the gradations with plasticity indices of different soils was also characterized.
\end{abstract}

Key words: Dry unit weights, plastic limits, plasticity index, shear stress and internal friction angle.

\section{INTRODUCTION}

The physical properties of soils are helpful to both agricultural and civil engineering problems. The most important physical properties are size, shape, plasticity characteristics, water content and the other properties are specific gravity, dry unit weight, liquid limit, plastic limit, uniformity co-efficient and strength parameters like $c$ and $\varphi$, etc. These properties of soils for all locations are necessary to determine to apply it in solving practical problems in the area. The index properties of soils give some information about the engineering properties. The practical application of different types of soil to specific situations requires knowledge of the relevant parameters and this information has to be obtained by experiment. These properties are, therefore, helpful to both agricultural and civil engineering problems in the design of important structures. Knowledge of the physical properties of soil helps in making decision for a process related to the field operations in agricultural. If I have

\footnotetext{
* Corresponding author: Lecturer, SARD, BOU. E-mail: serazsard4@yahoo.com

C) 2006, School of Agriculture and Rural Development, Bangladesh Open University. All rights reserved.
} 
knowledge of moisture content in soil, it is necessary in soil compaction control, in determining consistency limits of soils and for the calculation of the stability of all kinds of earth works and foundations (Leonard, 1962).

Shear strength is one of the physical properties of soil which influences agricultural practices and their productions. The main application of measurements of the shear strength of top soils has been to problems connected with agricultural implements and the wheels and tracts of tractors and tanks. It is very important as the reliability and economy of construction depend on the correctness of measurements of shear strength (Hvorslev, 1960). The stability of slopes, the bearing capacity of foundation, the lateral pressure exerted by soil on retaining walls and similar structures are all dependent on the shear strength characteristics of soil (Karol, 1970). Engineer, architect, builder or owner have need plans to build the foundations of structure, a high way, a rail way, water way or an airport run way can afford to ignore the problem of investigating the physical properties of soils due to moisture holding. Through investigation of soil properties is the best way to avoid failure of "soil structure" system and the exploitation, maintenance, legal, and financial troubles which may ensue. If the problems of soil are properly studied and the site explored, and the results of soil exploration correctly understood and intelligently applied to design and construction of earth works and structural foundations, failure can be avoided. The solution of foundation problems, therefore, requires a proper understanding of the properties and behaviour of the soils (Ramiah, 1981).

Keeping the above discussion into consideration the study was undertaken to determine the different properties of soils with variations and find out the relationship of these properties at seven locations in Mymensingh district.

\section{THEORY AND METHODOLOGY}

In this study soil samples were collected from seven location of Mymensingh district and these are from the area of BINA, Valuka, Muktagacha, Trisal, Madhupur, Chorkhai and Shomvoganj. About 5 $\mathrm{kg}$ of soil was collected from each place at a depth of 6 inch and then put in airtight bags to be used as sample soil to determine the different properties.

\section{Determination of Water Content}

The water content is the ratio of weight of water to the weight of soils in a given mass of soil (Punmia, 1988). The water content of the soil solids was determined by standard oven-dry method.

\section{Determination of Specific Gravity}

Specific gravity is the ratio of the weight of given volume of soil solids at a given temperature to the weight of an equal volume of distilled water at that temperature. If all the internal voids of soil particles (permeable and impermeable) are excluded for determining the true volume of soils, the specific gravity obtained is called the absolute or true specific gravity. The specific gravity of soil is determined by density bottle method.

\section{Determination of Dry Unit Weight}

The dry unit weight is the weight of soil per unit volume of the soil mass. As the bulk unit weight and the water content were determined the dry unit weight was then determined. Dry unit weight of soil was determined by the core cutter method.

\section{Consistency Limits/Atterberg's Limits}

The consistency of a fine-grained soil is the physical state in which it exists. It is used to denote the degree of fineness of a soil. Consistency of a soil is indicated by such terms as soft, firm or hard. In 1911, a Swedish agriculture engineer Atterberg mentioned that a fine-grained soil could exist in four states, namely, liquid, plastic, semi-solid or solid state. The water contents at which the soil changes from one state to the other are known as consistency limits or Atterberg's limits.

\section{Determination of Liquid Limit}

Liquid limit is the water content corresponding to the arbitrary limit between liquid and plastic state of consistency of soil. It is defined as the minimum water content at which the soil is still in the liquid 
state, but has a small shearing strength against following which can be measured by standard available means. With reference to the standard liquid limit device, it is defined as the minimum water content that a part of soil cut by a grove of standard dimension, will flow together for a distance of $12 \mathrm{~mm}$ under an impact of 25 blows in the device. The liquid limit of soil can be determined by Casagrande's method, one point method and cone penetrometer method (Arora, 1989). In this study liquid limit was determined by using the Cassagrande's method.

\section{Determination of Plastic Limit}

Plastic limit is the water content corresponding to an arbitrary limit between the plastic and the semi-solid states of consistency of soil. It is defined as the minimum water content at which a soil will just begin to crumble when rolled into a thread approximately $3 \mathrm{~mm}$ in diameter (Punmia, 1988). To determine the plastic limit, a portion of air-dried soil sample was taken and then allowed to pass through the $425 \mu$ ASTM sieve. About $20 \mathrm{gm}$ of soil passing through the sieve was mixed to sufficient amount of distill water to make it plastic enough to be shaped into a ball. Sufficient pressure was applied to roll the mass into a thread of $3 \mathrm{~mm}$ in diameter throughout its length without crack formation. The plastic soil was taken in the oven for 24 hours at $105^{\circ} \mathrm{C}$.

\section{Determination of Plasticity Index}

The range of consistency within which a soil exhibits plastic properties is called plastic range and is indicated by plasticity index. The plasticity index is defined as the numerical difference between the liquid limit and the plastic limit of a soil.

\section{Determination of Soil Classification:}

Collected soil sample was classified in different system such as American Association of State Highway Transportation Officials (AASHTO) and Unified Soil Classification (USC) System.

\section{Determination of $\mathbf{c}$ and $\varphi$ by Shear Box Test}

The best available failure theory, which appears to apply a wide range of soils, is the Mohr Coulomb failure criterion that is represented by the simple linear equation as:

$$
\begin{aligned}
& \tau=\mathbf{C}+\mathbf{s t a n} \varphi \\
& \text { Where, } \tau=\text { Shear stress, } \mathrm{kN} / \mathrm{m}^{2} \\
& \mathrm{c}=\text { Cohesion or adhesion between the surface of the soil particles, } \mathrm{kN} / \mathrm{m}^{2} \\
& \varphi=\text { Internal friction angle of the soil, degrees. }
\end{aligned}
$$

The actual value of $c$ and $\varphi$ depend both the drainage and consolidation history of the specimen being examined. The current practice is to $c$ and $\varphi$ as mathematical parameters that represent the failure conditions for a particular soil under given conditions. Values of $c$ and $\varphi$ were determined by shear box apparatus. The values of $c$ and $\varphi$ soils were determined at their liquid and plastic limits. Required amount of water was mixed thoroughly with soil. A portion of the soil was taken for shear box test. Tests were performed for different normal loads. Load was applied to the load hanger and the reading corresponding to shear load was taken by the proving ring. Hence normal stress and shear were determined by dividing the normal load and shear load with the area of the shear box respectively. The strength parameters $c$ and $\varphi$ were obtained from the graph analytically. The variation of $c$ and $\varphi$ values varies with the values of plastic limit, liquid limit and plasticity index.

\section{RESULTS AND DISCUSSION}

The values of water content, specific gravity, dry unit weight, liquid limit, plastic limit and plasticity index of the soils are given in Table 1 . The water contents of soils were found to vary for different locations. The dry unit weight and specific gravity of soils were varied in the morphology of soils at different locations. This may be due to particle size, presence of organic substance or most likely due to variation in mineral constituents (Arora, 1989). This might be due to accumulation of more organic materials in locations of lower elevation. The variation is due to the particle size rather than the variation in mineral constituents is most likely. The specific gravity for most natural soil falls in the range of 2.65 to 2.80 for inorganic soil (Arora, 1989). The values of specific gravity as obtained 
from experiment were within this limit and these are more or less similar. Hence the soils can be considered mostly inorganic. The liquid limit of soils in seven locations was found different. This limits depends upon the amount and nature of the present colloidal materials. The liquid limit signifies the moisture content at which the moisture films become so thick that cohesion is decreased and the soil mass flows under an applied force. It also depend upon the number of films that are present essentially it is the moisture content at which most of the films coalesce to fill the majority of the pore space or in terms of the physical state of the water present. The ratio of the socalled rigid water to the unoriented becomes so small that there is little bonding force between surfaces (Gulati, 1978). The plastic limits varied at various places. The variations of plastic limit at different locations depend upon soil particle size, mineral constituents, pressure and water absorbed condition. Optimum plasticity is obtained when the adsorbed water layers are oriented enough to produce a strong bond between adjacent particles but sufficiently thick to reduce rigidity of the water the boundary of adjacent absorbed water.

\section{Table 1. Properties of selected soils at different locations}

\begin{tabular}{lcccccc}
\hline $\begin{array}{c}\text { Locations/ } \\
\text { Sites }\end{array}$ & $\begin{array}{c}\text { Water } \\
\text { content } \\
(\%)\end{array}$ & $\begin{array}{c}\text { Specific } \\
\text { gravity } \\
\mathrm{G}\end{array}$ & $\begin{array}{c}\text { Dry unit } \\
\text { weight, } \\
\mathrm{kN} / \mathrm{m}^{3}\end{array}$ & $\begin{array}{c}\text { Liquid limit } \\
(\%)\end{array}$ & $\begin{array}{c}\text { Plastic limit } \\
(\%)\end{array}$ & $\begin{array}{c}\text { Plasticity } \\
\text { index } \\
(\%)\end{array}$ \\
\hline \hline BINA & 15.50 & 2.67 & 17.61 & 32.25 & 16.00 & 16.25 \\
Valuka & 18.25 & 2.66 & 16.50 & 31.50 & 17.00 & 14.50 \\
Muktagacha & 16.50 & 2.68 & 17.00 & 30.50 & 15.50 & 15.00 \\
Trisal & 19.00 & 2.70 & 17.50 & 35.50 & 18.50 & 17.00 \\
Madhupur & 17.50 & 2.69 & 15.50 & 34.00 & 16.00 & 18.00 \\
Chorkhai & 16.00 & 2.72 & 16.40 & 30.80 & 17.20 & 13.60 \\
Shomvoganj & 14.00 & 2.65 & 16.20 & 29.50 & 14.00 & 15.50 \\
\hline
\end{tabular}

The classification in different systems indicated the similitude of soils at different locations, which is shown in Table 2. The cohesion (c) and the internal friction $(\varphi)$ of these seven locations are given in Table 3. It was found that cohesion decreased and increased at different locations inversely to plastic limits. But the internal friction angles were more or less similar for soils of different locations. It was observed that moisture content little influence on the internal friction angle of the soil but the cohesion of this soil was found to increase with the increase in moisture content. The $c$ and $\varphi$ values were found as more or less same for plastic limit (Hoque, 1991). It was found that the values of liquid limit, plastic limit and plasticity index for all locations decreased with the increase were found to have little influence on those values. The soil properties at a site may show large local variations, yet there may be no general trends to the variations, and the average properties may be essentially the same in all portion of the site.

Table 2. Classification of soils in different classification system

\begin{tabular}{lccclcc}
\hline Locations/ Sites & $\begin{array}{c}\text { Sand } \\
(\%)\end{array}$ & $\begin{array}{c}\text { Silt } \\
(\%)\end{array}$ & $\begin{array}{c}\text { Clay } \\
(\%)\end{array}$ & $\begin{array}{l}\text { Textural } \\
\text { classification }\end{array}$ & AASHTO & USC \\
\hline \hline BINA & 28.44 & 40.00 & 31.56 & Clay loam & A-6 & $\mathrm{CL}$ \\
Valuka & 6.24 & 72.00 & 21.76 & Silty loam & $\mathrm{A}-4$ & $\mathrm{ML}$ \\
Muktagacha & 2.24 & 78.00 & 19.76 & Silty loam & $\mathrm{A}-4$ & $\mathrm{ML}$ \\
Trisal & 44.24 & 46.00 & 9.76 & Loam & $\mathrm{A}-2-4$ & $\mathrm{M}$ \\
Madhupur & 14.24 & 50.00 & 35.76 & Silty clay loam & $\mathrm{A}-5$ & $\mathrm{MH}$ \\
Chorkhai & 28.24 & 54.00 & 17.76 & Silty loam & $\mathrm{A}-4$ & $\mathrm{ML}$ \\
Shomvoganj & 16.24 & 74.00 & 9.76 & Silty loam & $\mathrm{A}-4$ & $\mathrm{ML}$ \\
\hline
\end{tabular}


Table 3. The values of $\mathrm{c}$ and $\varphi$ of soils of different locations at plastic limit

\begin{tabular}{lcc}
\hline Locations/Sites & \multicolumn{2}{c}{ At plastic limit } \\
& Cohesion $\left(\mathrm{kN} / \mathrm{m}^{2}\right)$ & Internal friction angle, degree \\
\hline \hline BINA & 0.27 & 13.00 \\
Valuka & 0.37 & 18.00 \\
Muktagacha & 0.27 & 14.00 \\
Trisal & 0.34 & 12.50 \\
Madhupur & 0.26 & 14.50 \\
Chorkhai & 0.23 & 17.00 \\
Shomvoganj & 0.27 & 19.00 \\
\hline
\end{tabular}

The relationship between the percent of sand, silt and clay with cohesion at plastic limit and regression lines were drawn (Figs. 1, 2 and 3) and equations are given here under.

$$
\begin{aligned}
& y=5175.2 x^{2}-3117.2 x+507.64 \text { (for sand) } \\
& y=6780.3 x^{2}-4070.5 x+644.64 \text { (for silt) } \\
& y=7116.7 x^{2}-4235.8 x+664.4 \text { (for clay) }
\end{aligned}
$$

From figures 1 and 2 cohesion was observed insignificant for sand and silt $\left(r^{2}=0.1475\right.$ and $r^{2}=$ $0.1882)$ and figure 3 it was observed significant for clay $\left(r^{2}=0.2166\right)$ soil. The percent of sand, silt and clay increased with decrease of cohesion at plastic limit condition.

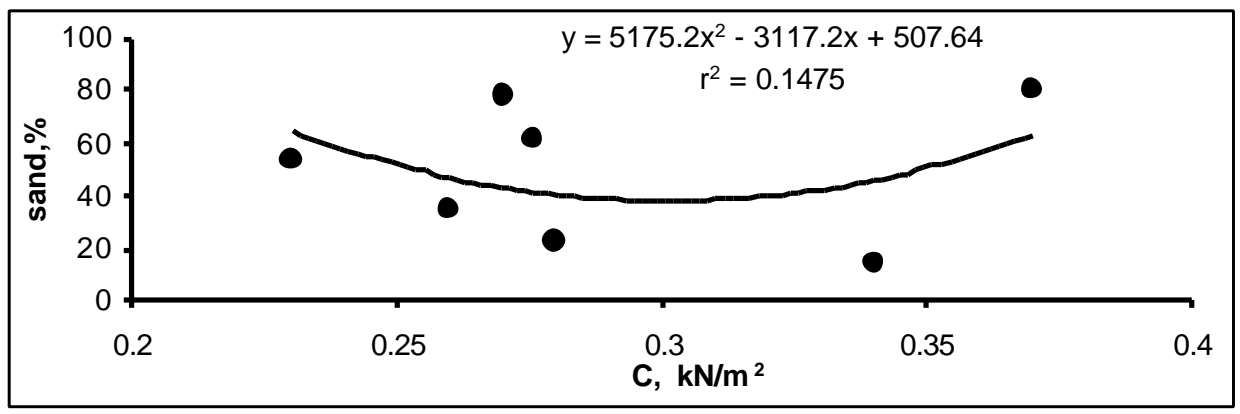

Fig. 1. Relationship between the percent of sand and cohesion at plastic limit

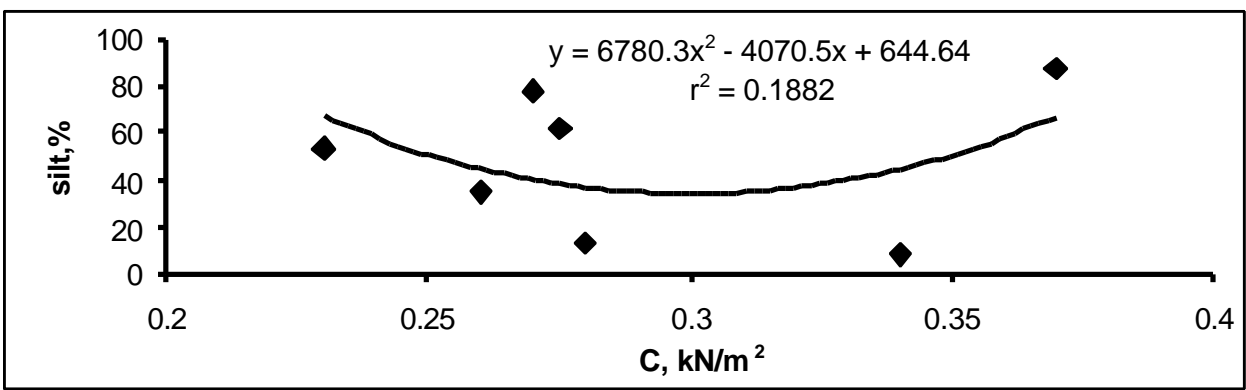

Fig. 2. Relationship between the percent of silt and cohesion at plastic limit 
Md. Tohidul Islam et al.

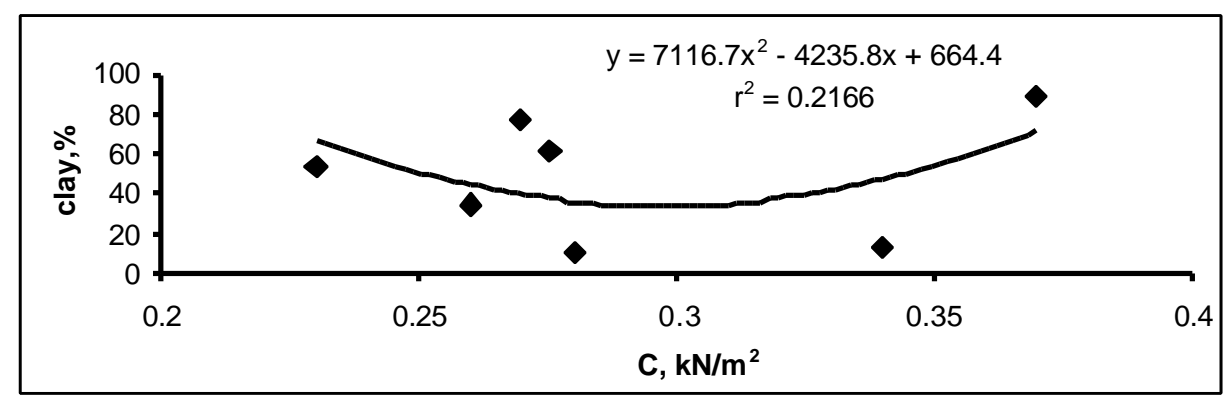

Fig. 3. Relationship between the percent of clay and cohesion at plastic limit

\section{LITERATURE CITED}

Arora, K. R. 1989. Soil Mechanics and Foundation Engineering. Standard Publishers Distributors, Delhi. 1218 pp.

Gulati, S. K. 1978. Engineering Properties of Soils. Tata McGraw Hill Publishing Co. Ltd. New Delhi. 9-11 pp.

Hoque, M. N. 1991. Estimating Soil Strength from a two point Indentation Test. Unpublished [PhD Thesis], Department of Agricultural Environmental Science, The University of Newcastle upon Type, UK. 70 pp.

Hvorslev, J. 1960. Physical Component of Shear Strength of Saturated Clays. Proc. Resi, Conf. ASCE.

Karol, R. H. 1970. Soils and Soil Engineering. Prentice-Hall, Inc. Englewood Cliffs, New Jersey. 67-124 pp.

Leonard, G. C. 1962. Foundation Engineering. McGra- Hill Book Co. Inc., New York.

Punmia, K. R. 1988. Soil Mechanics and Foundations Engineering. Standard Publishers Distributors, New Delhi. $915 \mathrm{pp}$.

Ramiah, B. K. 1981. Soil Mechanics and Foundations Engineering. Oxford and IBH Publishing Co., New Delhi. 